\title{
ISOLATION AND CHARACTERIZATION OF BACTERIAL FLORA FROM FARMHOUSE FERMENTED MILK PRODUCTS OF SERBIA AND MONTENEGRO
}

\author{
MARTINOVIĆ ALEKSANDRA*, RADULOVIĆ ZORICA**, WIND ANETTE***, JANZEN T*** \\ and OBRADOVIĆ $D * *$ \\ * Institute of Meat Hygiene and Technology, Belgrade; \\ **Agricultural Faculty, Dep. of industrial microbiology, Belgrade, \\ ${ }^{* *}$ Chr. Hansen A/S, Dep. of Appl. Biotechnology, Hoersholm, Denmark
}

(Received 12. April 2005)

The natural community of lactic acid bacteria isolated from farmhouse fermented milk products has been investigated. In such products, where no starters are added, fermentation occurs as a result of natural flora present in the surrounding environment. A total of 200 isolated strains were examined for their acidification activity and EPS formation. Out of the 200 isolated strains, 27 strains were selected for further investigation. They were further identified by 16S rRNA sequencing in order to obtain the identification at species level, which showed that 14 strains belong to Lactococcus lactis subsp. lactis, 10 of them to Lactobacillus $s p$ and 3 strains belongs to Leuconostoc sp. To differentiate between strains the pulsed-field gel electrophoresis (PFGE) patterns, of 15 isolated lactococcal strains, was generated using Smal or Ascl. Unrelated strains yielded different patterns of digestion products. The plasmid isolation of these strains has also been conducted in order to compare these results to patterns of PFGE. Phage typing of the Lactococcus sp. strains has been conducted. All lactococcal strains were resistant against 41 phages (Chr. Hansen phage collection) representing the major phage groups known for Lactococcus. These results indicate that the strains represent a possible tool for cultures that have not been exposed to any industrial selection.

Key words: $L A B$, pulsed gel field electrophoresis (PFGE), plasmid isolation, phage typing.

\section{INTRODUCTION}

Lactic acid bacteria (LAB) are of great importance for the dairy industry, as well as for the production of other fermented foods and food supplements. Farmhouse fermented milk products are made using ancient technologies belonging to the country or area where this food is produced and could be considered as a part of the country's cultural heritage. The natural community of 
LAB isolated from farmhouse fermented milk products of Serbia and Montenegro represents a reservoir for obtaining new strains with different features, which could be used in the dairy industry. These strains differ in many important properties, such as rate and extent of acid production, sensitivity to bacteriophage infection, ability to break down the casein etc.

The identification of LAB has been based mainly on the fermentation of carbohydrates, colony and cell morphology and Gram staining. These methods are still widely used. However, in recent years the taxonomy has changed considerably with increasing knowledge of the genomic structure and phylogenetic relationships between various species of LAB (Tynkkynen et al., 1999). Strain classification has been accomplished by a number of different approaches. Species identification is often based on $16 \mathrm{~S}$ ribosomal DNA sequence analysis. Pulsed-field gel electrophoresis (PFGE) is used to compare restriction patterns of genomic DNA of individual isolates from a given species and it is considered to be a very useful tool for strain differentiation (Tanasken et al., 1990).

Plasmid profile patterns can be used to support data on strain relatedness obtained by PFGE (Davies et al., 1981), or in combination with PFGE it might give a better differentiation than neither of the two methods alone.

The main commercial problems in the dairy industry are caused by the infection of bacteriophages and they are reflected in great economical losses (Higgins and Sandine, 1997). It is therefore important that new strains are resistant to the bacteriophage groups most commonly found in the dairy environment.

\section{MATERIAL AND METHODS}

Farmhouse fermented milk products. Thirty five cheeses, corresponding to ten different types of cheese, as well as five samples of skimmed cream belonging to two different types of cream were collected at various locations in Montenegro and Serbia. Sensory evaluation of the products has been conducted according to the scheme given by Dozet et al., (1996).

Bacterial strains and phages. Twenty grams of cheese or cream were diluted in $180 \mathrm{ml}$ of $2 \%$ sodium citrate solution and homogenized in a Stomacher. Lactobacillus strains were isolated on MRS 5.4 medium (De Man et al., 1960), incubated at $37^{\circ} \mathrm{C}$ under anaerobic conditions for 48 hours, while Lactococcus strains were isolated on M17 medium (Terzagi and Sandine, 1975) supplemented with $5 \mathrm{~g}$ of lactose per liter and incubated at $20^{\circ} \mathrm{C}$ under aerobic conditions for 24 hours. Leuconostoc strains were isolated on LD medium supplemented with vancomycin (Vogensen, 1987) and incubated at $25^{\circ} \mathrm{C}$ under aerobic conditions for 120 hours. The 41 different phages were provided from Chr. Hansen's phage collection.

Phenotypic characterization. All strains were tested for their Gram reaction, catalase, using $3 \mathrm{~g} \mathrm{H}_{2} \mathrm{O}_{2} / \mathrm{l}$ and cell shape by phase contrast microscopy of overnight cultures. Gram- positive and catalase-negative isolates were identified at the species level by testing their carbohydrate fermentation ability using API 50 CHL (bioMerieux, France) for rod-shaped organisms and Rapid ID 32 Strep for 
coccus-shaped organisms. The APILAB Plus version 4.0 program was used to analyse the fermentation profiles obtained with the identification strips.

Acidification activity was determined in autoclaved (5 min at $121^{\circ} \mathrm{C}$ ) $1 \%$ reconstituted skimmed milk. A $10 \mathrm{ml} / \mathrm{l}$ inoculum was used at temperatures corresponding to growth conditions of every isolated strain and $\mathrm{pH}$ values were measured after 2, 4, 6, 8, 24 and 48 hours.

Exopolysaccharide formation. EPS production was determined by qualitatively measuring of the degree of ropiness of cultures grown on agar plates for 24 hours. A strain was considered positive when a long, ropy filament appeared when the colony was lifted with an inoculation loop.

\section{PCR amplification of the 16 S ribosomal DNA ( $R$ DNA) variable region}

DNA was isolated from $2 \mathrm{ml}$ overnight cultures with the help of the DNeasy Tissue Kit (Qiagen) according to the procedure given by the supplier.

Primers were designed to anneal and amplify highly conserved regions of the 16S rRNA gene. The primers used for PCR were 616VLAB: 5'AGAGTTTGATCYTGGCTCAG3' and 612R: 5'GTAAGGTTCTTCGCGT3'. Each reaction mixture contained $1,25 \mathrm{mM} \mathrm{MgCl}_{2}, 10 \mu$ of $10 x$ Taq buffer, $0,2 \mathrm{mM} \mathrm{dNTP}$, 100 pmol of 616VLAB and 612R each, 1,5 U of Taq DNA polymerase and 64,7 $\mu \mathrm{l}$ of sterile bidistilled water. The PCR program comprised 35 cycles of denaturation for $1 \mathrm{~min}$ at $94^{\circ} \mathrm{C}$, annealing for $2 \mathrm{~min}$ at $48^{\circ} \mathrm{C}$ and extension for $3 \mathrm{~min}$ at $72^{\circ} \mathrm{C}$. PCR products were separated by electrophoresis at $100 \mathrm{~V}$ for $30 \mathrm{~min}$ on a $1 \%$ agarose gel (Gibco BRL) in 1xTAE buffer with $1 \mathrm{~kb}$ ladder as molecular size standard. PCR products were extracted from the gel with Qiaquick GEL Extraction Kit (Qiagen). The sequence of both strands around the first $500 \mathrm{bp}$ of the PCR product was determined. Sequencing reactions were carried out with primers 616VLAB and 610R: 5'ACCGCGGCTGCTGGCAC3' with the BigDye ${ }^{\circledR}$ Terminator v3.1 Cycle Sequencing Kit (Applied Biosystems) according to the manufacturer. The sequence reactions were separated on an ABI PRISM 310 Genetic Analyzer. Analysis of the sequences was carried out with the help of the arb program package (TU Munich, Germany).

\section{Preparation of genomic DNA in situ in agarose blocks}

The principle of the method is described by Hung and Banoziulis (1990). A culture of selected LAB strains was grown overnight in $10 \mathrm{ml}$ of medium supplemented with $20 \mathrm{mM}$ DL-Threonine. The overnight culture was adjusted to an $\mathrm{OD}_{600}$ between 0.5 and 1 and $10 \mathrm{ml}$ was harvested by centrifugation at 5-6000 rpm for $10 \mathrm{~min}$, washed in $10 \mathrm{ml} 50 \mathrm{ml}$ EDTA pH 8.5 and resuspended in 300 ?! $50 \mathrm{ml}$ EDTA pH 8.5 per OD-unit measured. $125 \mu \mathrm{l}$ of cell suspension was mixed with $750 \mu$ l of $1 \%$ low melting point agarose and $250 \mu$ l of this suspension was pipetted into each hole of a plug mold. Agarose blocks (inserts) were transferred to $3 \mathrm{ml}$ of lysozyme solution and incubated $4-5 \mathrm{hrs}$ or over night at $37^{\circ} \mathrm{C}$. The lysozyme solution was removed and $3 \mathrm{ml}$ of NDS-Proteinase $\mathrm{K}$ solution was added and the inserts were further incubated over night at $50^{\circ} \mathrm{C}$. The inserts were washed for 4-5 times in $50 \mathrm{mM}$ EDTA pH 8.5 and stored at $4^{\circ} \mathrm{C}$. 
Digestion of DNA in agarose blocks. Slices of agarose blocks (1-2 $\mathrm{mm}$ thick) were equilibrated in TE buffer for $1 / 2$ hrs at $4^{\circ} \mathrm{C}$ to remove the EDTA, then equilibrated in restriction enzyme buffer for $1 / 2$ to $2 \mathrm{hrs}$ at $4^{\circ} \mathrm{C}$ before adding the enzyme. For lactococcal and Leuconostoc strains 20-40 U of SmaI were used and 20 units Ascl for Lactobacillus strains. Incubation took place overnight at the temperature recommended by the manufacturer of the enzyme.

PFGE. Samples were electrophoresed trough $1.1 \%$ agarose gels in $1 / 2 \times$ TBE for $24 \mathrm{hrs}$ at $14^{\circ} \mathrm{C}$ at $5.3 \mathrm{~V} / \mathrm{cm}$ in Biorad CHEF-chamber. Pulse times were 3 to $80 \mathrm{~s}$ with a non-linear ramp of -1.53 for SmaI and 2 to $30 \mathrm{~s}$ with a linear ramp for Ascl. Gels were stained with $0.5 \mathrm{mg}$ of ethidium bromide per liter of water and visualized over UV light to detect DNA fragments.

Plasmid profiling. An overnight culture of cells was collected by centrifugation at $15.000 \mathrm{~g}$ and plasmid DNA was isolated as described by Andersson and McKay (1983). DNA was then resuspended in $20 \mu \mathrm{l}$ of TE+RNAse and electrophoresed on a $0.7 \%$ agarose gel for $2.5 \mathrm{hrs}$ at $100 \mathrm{~V}$. Gels were stained and visualized as described for PFGE.

Phage typing. The method was used to test the phage sensitivity of lactococcal strains to the collection of 41 phages. Overnight cultures in M17 broth supplemented with $0.5 \%$ lactose were mixed with $3 \mathrm{ml}$ of melted top M17 agar also supplemented with $0.5 \%$ of lactose, and poured onto the bottom of agar plates. Ten fold serial dilutions of phage lysates with $1 / 4$ strength Ringer's solution were spotted onto the surface of the top agar (10 $\mu \mathrm{l}$ per dilution) and were incubated face up at $30^{\circ} \mathrm{C}$ overnight.

\section{RESULTS}

Of 351 isolated strains, 27 strains were selected for further analysis. Out of 27 selected strains, 15 strains were gram-positive, homofermentative, catalase negative cocci occurring in pairs or short chains, 10 strains were gram positive, catalase negative, homofermentative rods, while 2 strains were gram-positive, catalase negative, heterofermentative coccoid rods. Four of the 27 selected strains "showed ropiness" ( SO25-2, SO36-2, SO47-3, SO52-3) and they were labeled as EPS ${ }^{+}$.

Results of acidification and post acidification ability of the examined strains are shown in Graph1. Initial pH value of milk varied between 6,55 and 6,58. On the basis of acid production during 24 hours in $1 \%$ reconstituted skimmed milk the 27 examined strains can be classified into 3 groups. First group (17 strains: SO1-1, SO2-1, SO3-2, SO4-1, SO5-1, SO18-3, SO19-2, SO19-3, SO36-1, SO36-2, SO441, SO47-1, SO47-3, SO49-2, SO52-3, SO56-3, SO57-1) showed fast acidification ability and after 24 hours the $\mathrm{pH}$ value in these strains was from 4,31 to 4,65. In the second group were 7 strains (SO25-2, SO53-5, SO53-7, SO54-2, SO55-9, SO564, SO56-5) and the $\mathrm{pH}$ value after 24 hours was from 5,52 to 6,47 which is characterized as a slow acidification ability. In the third group there were only three strains (SO47-2-a, SO47-2-b, SO49-1) that were characterized having low acidification ability with an absence of curd formation. The $\mathrm{pH}$ values in the third group were 5,48, 5,58 and 6,32 respectively. The $\mathrm{pH}$ value in the period from 24 to 
Acta Veterinaria (Beograd), Vol. 55. No. 4, 307-318, 2005.

Martinović Aleksandra et al. Isolation and characterization of bacterial flora

from farmhouse fermented milk products of Serbia and Montenegro

48 hours has decreased by 0 to $0,49 \mathrm{pH}$ units which indicates that all examined strains are characterized by low post acidification ability.

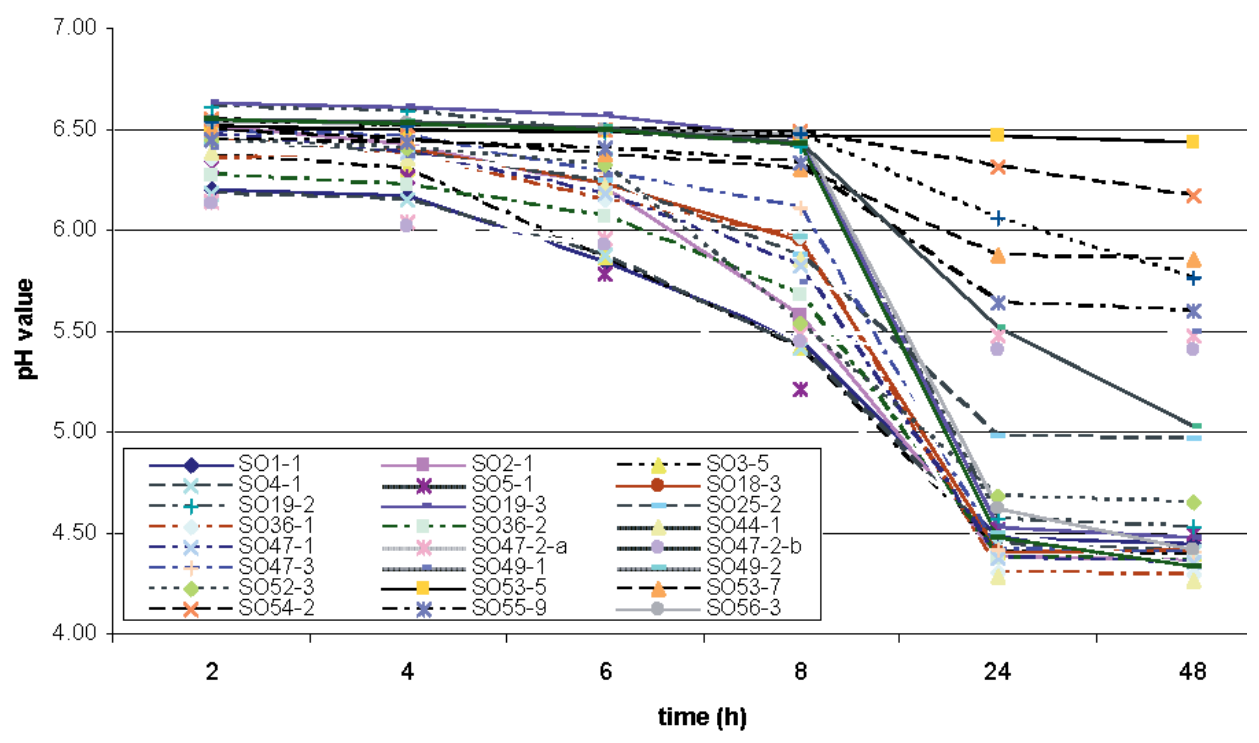

Figure 1. Degree of acidification in $1 \%$ skim milk

Phenotypic characterization based on sugar fermentation assays by Rapid ID 32 Strep, resulted in the identification of 12 isolates (SO1-1, SO3-2, SO18-3, SO19-3, SO36-1, SO47-1, SO49-2, SO52-3, SO54-2, SO55-9, SO56-3, SO57-1) as Lactococcus lactis subsp. lactis, 2 isolates as Lactococcus lactis subsp. cremoris (SO4-1, SO56-5) and three isolates as Leuconostoc spp. (SO47-2-a, SO47-2-b, SO49-1). Results obtained by APIL $50 \mathrm{CHL}$ sugar fermentation assays have shown that 7 strains (SO2-1, SO5-1, SO19-2, SO25-2, SO36-2, SO44-1, SO47-3) belong to Lactobacillus plantarum, 1 strain belongs to Lactobacillus brevis /plantarum (SO53-7), 1 strain belongs to Lactobacillus pentosus (SO53-5) and 1 strain belongs to Lactobacillus paracasei (SO56-4). The percentage of identification obtained by Rapid ID 32 Strep and API 50 CHL was from 89 to $98 \%$.

Results of the analysis are shown in Tables 1 and 2.

\section{PCR Reaction and partial $16 S$ rDNA sequencing}

Species identification was performed using sequencing of the16S rDNA variable region followed by alignment of sequences to the available $16 \mathrm{~S}$ ribosomal sequences using the software developed by The Technical University of Munich. As seen in Table 1, the phenotypic identification of Lactococcus lactis was confirmed by the16S rDNA identification for all isolates. In two instances the subspecies assignments were different according to the two methods. The subspecies assignments should either be repeated or confirmed using another method. 
Table 1. Summary of results for Lactococcus $s p$.

\begin{tabular}{|c|c|c|c|c|c|c|c|}
\hline Strain & $\begin{array}{c}\text { Phenotypic ID } \\
\text { API }\end{array}$ & $\begin{array}{c}16 \mathrm{~S} \text { rRNA } \\
\text { ID }\end{array}$ & $\begin{array}{l}\text { PFGE } \\
\text { group }\end{array}$ & Plasmid & $\begin{array}{l}\text { Acidifi- } \\
\text { cation } \\
\text { group }\end{array}$ & $\begin{array}{c}\text { EPS } \\
\text { produc- } \\
\text { tion } \\
\end{array}$ & $\begin{array}{l}\text { Phage } \\
\text { sensi- } \\
\text { tive }\end{array}$ \\
\hline SO1-1 & $\begin{array}{l}\text { Lc. lactis } \\
\text { subsp. lactis }\end{array}$ & $\begin{array}{l}\text { Lc. lactis } \\
\text { subsp. lactis }\end{array}$ & u & yes & fast & - & - \\
\hline SO3-2 & $\begin{array}{l}\text { Lc. lactis } \\
\text { subsp. lactis }\end{array}$ & $\begin{array}{l}\text { Lc. lactis } \\
\text { subsp. lactis }\end{array}$ & u & yes & fast & - & - \\
\hline SO4-1 & $\begin{array}{l}\text { Lc. lactis } \\
\text { subsp. cremoris }\end{array}$ & $\begin{array}{l}\text { Lc. lactis } \\
\text { subsp. lactis }\end{array}$ & u & yes & fast & - & - \\
\hline SO18-3 & $\begin{array}{l}\text { Lc. lactis } \\
\text { subsp. lactis }\end{array}$ & $\begin{array}{l}\text { Lc. lactis } \\
\text { subsp. lactis }\end{array}$ & u & yes & fast & - & - \\
\hline SO19-3 & $\begin{array}{l}\text { Lc. lactis } \\
\text { subsp. lactis }\end{array}$ & $\begin{array}{l}\text { Lc. lactis } \\
\text { subsp. lactis }\end{array}$ & u & yes & fast & - & - \\
\hline SO36-1 & $\begin{array}{l}\text { Lc. lactis } \\
\text { subsp. lactis }\end{array}$ & $\begin{array}{l}\text { Lc. lactis } \\
\text { subsp. lactis }\end{array}$ & u & yes & fast & - & - \\
\hline SO47-1 & $\begin{array}{l}\text { Lc. lactis } \\
\text { subsp. lactis }\end{array}$ & $\begin{array}{l}\text { Lc. lactis } \\
\text { subsp. lactis }\end{array}$ & I & yes & fast & - & - \\
\hline SO49-2 & $\begin{array}{l}\text { Lc. lactis } \\
\text { subsp. lactis }\end{array}$ & $\begin{array}{l}\text { Lc. lactis } \\
\text { subsp. lactis }\end{array}$ & I & yes & fast & - & - \\
\hline SO52-3 & $\begin{array}{l}\text { Lc. lactis } \\
\text { subsp. lactis }\end{array}$ & $\begin{array}{l}\text { Lc. lactis } \\
\text { subsp. lactis }\end{array}$ & u & yes & fast & - & $(+)$ \\
\hline SO54-2 & $\begin{array}{l}\text { Lc. lactis } \\
\text { subsp. lactis }\end{array}$ & $\begin{array}{l}\text { Lc. lactis } \\
\text { subsp. lactis }\end{array}$ & $\|$ & nd & slow & - & - \\
\hline SO55-9 & $\begin{array}{l}\text { Lc. lactis } \\
\text { subsp. lactis }\end{array}$ & $\begin{array}{l}\text { Lc. lactis } \\
\text { subsp. lactis }\end{array}$ & u & yes & slow & - & - \\
\hline SO56-3 & $\begin{array}{l}\text { Lc. lactis } \\
\text { subsp. lactis }\end{array}$ & $\begin{array}{l}\text { Lc. lactis } \\
\text { subsp. lactis }\end{array}$ & u & yes & fast & - & - \\
\hline SO57-1 & $\begin{array}{l}\text { Lc. lactis } \\
\text { subsp. lactis }\end{array}$ & $\begin{array}{l}\text { Lc. lactis } \\
\text { subsp. lactis }\end{array}$ & u & yes & fast & - & - \\
\hline SO56-5 & $\begin{array}{l}\text { Lc. lactis } \\
\text { subsp. cremoris }\end{array}$ & $\begin{array}{l}\text { Lc. lactis } \\
\text { subsp. lactis }\end{array}$ & II & yes & slow & - & - \\
\hline
\end{tabular}

$\mathrm{u}=$ unique fingerprint, that is the genotype is different from all other isolates analyzed. nd $=$ not determined

The Leuconostoc isolates were species assigned to Leuc. mesenteroides, whereas the phenotypic identification only identified the strains to the genus level.

16S rDNA cannot distinguish between the closely related species $L b$. plantarum, $L b$. pentosus and $L b$. paraplantarum. Sequencing confirmed that the isolates identified as $L b$. plantarum by the phenotypic test do belong to the $L b$. plantarum-group of species.

In one case, SO56-4, gave conflicting results. The identifications will have to be repeated in order to get a proper species identification. 
Acta Veterinaria (Beograd), Vol. 55. No. 4, 307-318, 2005.

Martinović Aleksandra et al. Isolation and characterization of bacterial flora

from farmhouse fermented milk products of Serbia and Montenegro

Table 2. Summary of results for Lactobacillus sp.

\begin{tabular}{|c|c|c|c|c|c|c|c|}
\hline Strain & $\begin{array}{c}\text { Phenotypic ID } \\
\text { API }\end{array}$ & $\begin{array}{c}\text { 16S rRNA } \\
\text { ID }\end{array}$ & $\begin{array}{l}\text { PFGE } \\
\text { group }\end{array}$ & Plasmid & $\begin{array}{l}\text { Acidifi- } \\
\text { cation } \\
\text { group } \\
\end{array}$ & $\begin{array}{c}\text { EPS } \\
\text { produc- } \\
\text { tion } \\
\end{array}$ & $\begin{array}{l}\text { Phage } \\
\text { sensi- } \\
\text { tive } \\
\end{array}$ \\
\hline SO2-1 & $\begin{array}{l}\text { Lb. } \\
\text { plantarum }\end{array}$ & $\begin{array}{l}\text { Lb. plantarum- } \\
\text { pentosus group }\end{array}$ & III & yes & fast & - & nd \\
\hline SO5-1 & $\begin{array}{l}\text { Lb. } \\
\text { plantarum }\end{array}$ & $\begin{array}{l}\text { Lb. plantarum- } \\
\text { pentosus group }\end{array}$ & $\mathrm{u}$ & yes & fast & - & nd \\
\hline SO19-2 & $\begin{array}{l}\text { Lb. } \\
\text { plantarum }\end{array}$ & $\begin{array}{l}\text { Lb. plantarum- } \\
\text { pentosus group }\end{array}$ & $\mathrm{u}$ & yes & fast & - & nd \\
\hline SO25-2 & $\begin{array}{l}\text { Lb. } \\
\text { plantarum }\end{array}$ & $\begin{array}{l}\text { Lb. plantarum- } \\
\text { pentosus group }\end{array}$ & III & nd & slow & + & nd \\
\hline SO36-2 & $\begin{array}{l}\text { Lb. } \\
\text { plantarum }\end{array}$ & nd & $\mathrm{u}$ & yes & fast & + & nd \\
\hline SO44-1 & $\begin{array}{l}\text { Lb. } \\
\text { plantarum }\end{array}$ & $\begin{array}{l}\text { Lb. plantarum- } \\
\text { pentosus group }\end{array}$ & $\mathrm{u}$ & yes & fast & - & nd \\
\hline SO47-3 & $\begin{array}{l}\text { Lb. } \\
\text { plantarum }\end{array}$ & $\begin{array}{l}\text { Lb. plantarum- } \\
\text { pentosus group }\end{array}$ & $\mathrm{u}$ & yes & fast & + & nd \\
\hline SO53-7 & $\begin{array}{l}\text { Lb. brevis/ } \\
\text { plantarum }\end{array}$ & nd & $\mathrm{u}$ & yes & slow & - & nd \\
\hline SO56-4 & $\begin{array}{l}\text { Lb. paracasei } \\
\text { subsp. } \\
\text { paracasei }\end{array}$ & $\begin{array}{l}\text { Lb. plantarum- } \\
\text { pentosus group }\end{array}$ & $\mathrm{u}$ & yes & slow & + & nd \\
\hline SO53-5 & Lb. pentosus & nd & $\mathrm{u}$ & nd & slow & - & nd \\
\hline SO47-2 a & $\begin{array}{l}\text { Leuconostoc } \\
\text { spp. }\end{array}$ & $\begin{array}{l}\text { Leuc. } \\
\text { mesenteroides }\end{array}$ & IV & yes & low & - & nd \\
\hline SO47-2 b & $\begin{array}{l}\text { Leuconostoc } \\
\text { spp. }\end{array}$ & $\begin{array}{l}\text { Leuc. } \\
\text { mesenteroides }\end{array}$ & IV & yes & low & - & nd \\
\hline SO49-1 & $\begin{array}{l}\text { Leuconostoc } \\
\text { spp. }\end{array}$ & nd & IV & yes & low & - & nd \\
\hline
\end{tabular}

$\mathrm{u}=$ unique fingerprint, that is the genotype is different from all other isolates analyzed. $\mathrm{nd}=$ not determined

\section{PFGE method for strain differentiation}

The Ascl (Fig 2) and Smal (Fig 3) digestion patterns were examined over a range of electrophoretic conditions. Pulse times from 3 to $80 \mathrm{~s}$ gave a good separation of the majority of Smal digestion fragments of DNA from 14 strains of Lactococcus lactis and 3 strains of Leuconostoc mesenteroides. The number of Smal fragments varied from 15 to 20 .

Pulse times from 2 to $30 \mathrm{~s}$ gave a good separation of the majority of $\mathrm{Ascl}$ digestion fragments of DNA from 9 strains of Lactobacillus plantarum-group and 1 strain of Lactobacillus brevis. The number of Ascl fragments was 15 or more. For 27 examined strains PFGE typing revealed 22 different genotypes. Strains SO54-2 and SO56-5 and SO47-1 and SO49-2, as well as strains SO47-2-a, SO47-2-b and 
SO49-1 showed the same genotype and they may be considered to be identical or closely related groups of strains respectively.

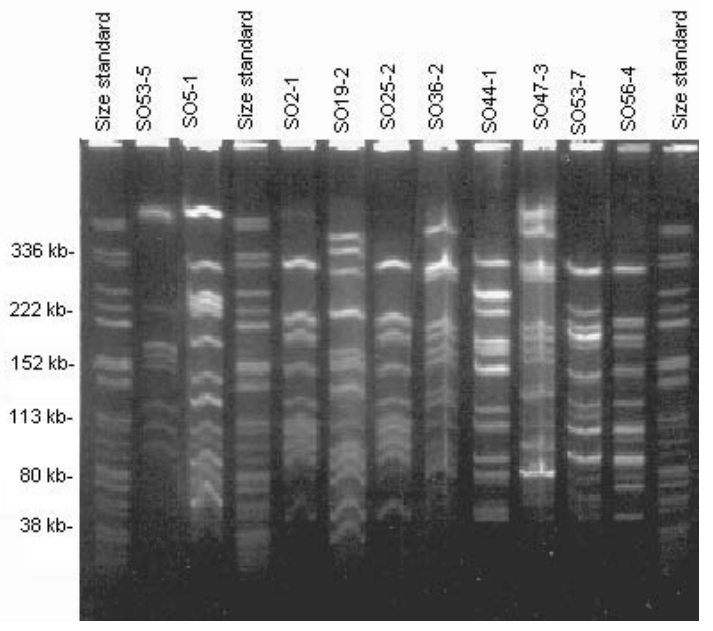

Figure 2. Smal fragments of Lactococcus and Leuconostoc

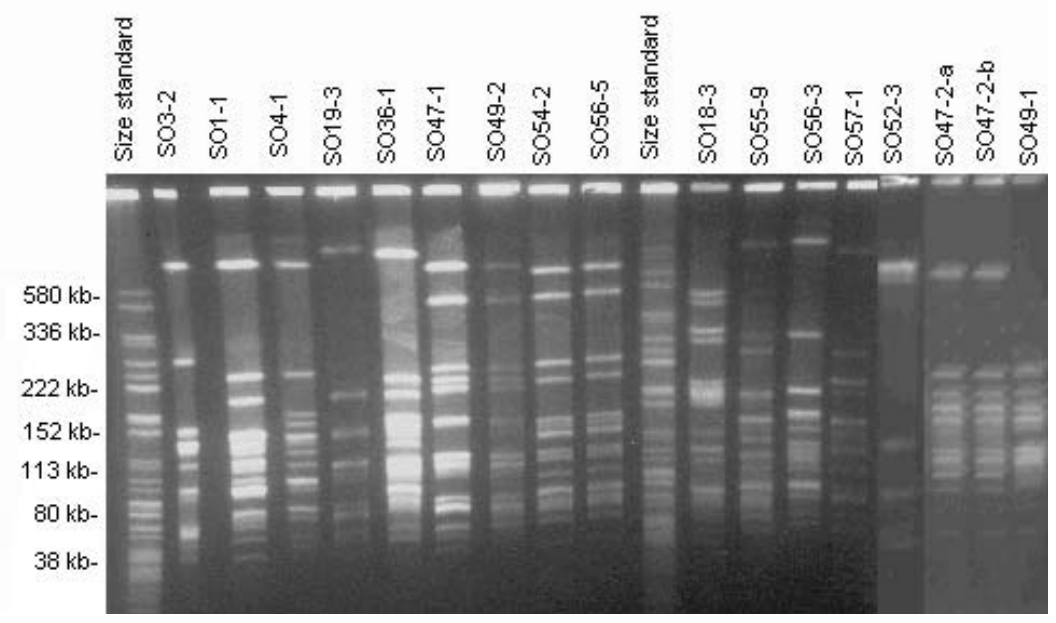

Figure 3. Ascl fragments of Lactobacillus isolates

\section{Plasmid isolation}

Plasmid analysis was performed on a number of isolates (Table 1). Most but not all strains have several plasmids (data not shown). The plasmid profile confirmed the genotypic grouping of SO47-1 and SO49-2 and of SO47-2a, SO47$2 \mathrm{~b}$ and SO49-1. The genotypic grouping of SO54-2 and SO56-5 as well as of SO2- 
Martinović Aleksandra et al. Isolation and characterization of bacterial flora

from farmhouse fermented milk products of Serbia and Montenegro

1 and SO25-2 was not confirmed because for some of the isolates the plasmid bands were barely visible on the gels.

\section{Bacteriophage resistance}

Bacteriophage sensitivity was examined for 14 strains (SO1-1, SO3-2, SO41, SO18-3, SO19-3, SO36-1, SO47-1, SO49-2, SO52-3, SO54-2, SO55-9, SO56-3, SO57-1, SO56-5) all belonging to Lactococcus lactis ssp. lactis. Sensitivity was determined towards the Chr. Hansen's collection of mesophilic bacteriophages. For SO52-3 turbid inhibition zones appeared for phages 15, 42, and 38. The strain was retested with higher dilutions of phage lysates. No turbid zones or plaques were detected in these higher dilutions. All other examined were resistant to all test phages strains.

\section{Organoleptic evaluation of fermented milk products}

The evaluation of autochthonous fermented milk products in this study was not exclusively hedonic. Sensoric evaluation of soft cheeses showed that most of them had specific soft cheese taste with milk-acid aroma and that they were all of good quality. Hard cheeses (such as Njeguski) were shown to have characteristics of the original cheese type: yellow color, pleasant taste and smell and few holes in the body. The sensory evaluation of cream showed that all samples were good quality, white to pale yellow in color, good texture and taste. The cream samples were typical, authentic and of good quality, with certain mistakes that usually follow home manufacture.

\section{DISCUSSION}

EPS produced by LAB significantly improves viscosity and some rheological features especially during the production of fermented milks. It has to be emphasized that in most mesophilic lactococci EPS production is plasmid encoded (Vedemuthu and Neville, 1986). Furthermore, for EPS producing bacteria it has been found that they have better phage resistance. The EPS test used in this study gives information about a strain's ability to produce EPS but it does not give any information about the characteristics of the produced EPS.

During the industrial production of different kinds of fermented milk products a very important feature is acid production by LAB that are used as starters. In some products it is important to lower the $\mathrm{pH}$ value to 4,6-4,8 where calcium is completely removed from the casein micelle, leaving free paracaseine, while in other products the desired pH value is between 5,0 to 5,2 where calcium is partly connected to the casein micelle (Salminen and von Wright, 1998). In commercial use of $L A B$ great attention is committed to the selection of strains that show fast acidification and low or absent post acidification. In this study we have concluded that the examined strains have low post acidification.

Proper species identification is necessary for the dairy industry. Often species determination is based on phenotypic tests such as sugar fermentation patterns but research over the last decade has shown that for many species this 
tool is not appropriate for the discrimination of species (Pot et al., 1993). A phylogenetic species determination is used nowadays and one of the most used methods to determine phylogenetic relationship is the alignment of sequences of the variable regions in $16 \mathrm{~S}$ or $23 \mathrm{~S}$ ribosomal DNA. In a few cases it is necessary to use methods alternative to rDNA sequence alignment to discriminate species. One example is the Lactobacillus plantarum-group of species including $L b$. plantarum, $L b$. pentosus and $L b$. paraplantarum, which can be discriminated by a multiplex PCR of the recA-gene (Torriani et al., 2001). In this study the phenotypic and molecular results agreed in most cases. For the final identification of the Lactobacillus plantarum group of isolates a multiplex PCR will have to be done. Subspecies assignment in Lactococcus lactis differs sometimes. It has been observed earlier that a strain can be genotypically subsp. cremoris but phenotypically behave as a subsp. lactis and vice versa (Urbach et al., 1997). In this study we have at least one strain that seem to behave oppositely in the two analyses, that is it is genotypically a subsp. lactis but phenotypically it is a subsp. cremoris.

PFGE-typing is regarded as one of the best techniques for the discrimination of bacterial strains. For example, in several studies on Lactobacillus, PFGE has been proved as a most powerful method in strain typing (Ferrero et al., 1996; Tynkkynen et al., 1999). The technique is based on the variation in the distribution of recognition sites for rare cutting restriction enzymes in the genome of bacterial strains. The resulting fragments can be separated according to size using a pulsed field gel electrophoresis technique (PFGE). Our results show that PFGE was suitable for the discrimination of strains within Lactococcus lactis and Lactobacillus as reported earlier by others (Le Bourgeois et al., 1989, Tanasken et al., 1990). Differences in PFGE profiles in strains belonging to the same species could be due to point mutations at the recognition sites of the restriction enzymes used. Chromosomal rearrangements such as deletions, insertions and inversions, described in Enterobacteria (Rilez and Anilionis, 1978) and Pseudomonas (Holloway and Morgan, 1986) could also be the reason for such differences. These rearrangements could be supported by transposable elements, integrated plasmids and prophages. The presence of large plasmids in a strain might also give rise to fragments that separate along with the genomic fragments in a PFGE. Approximate genome sizes can be determined by summing the sizes of the different PFGE fragments. Values of genome sizes determined in this study are between 2.0 to $2.7 \mathrm{Mbp}$ for Lactococcus. There is no significant difference between genome sizes for $L$. lactis subsp. lactis and $L$. lactis subsp. cremoris and they are similar to the results obtained by Le Bourgeois et al. (1989) and Jarvis et al. (1979).

In the examination of bacteriophage resistance in this study we have concluded that all strains are resistant to 41 phages from the Chr. Hansen phage collection. The turbid zones detected for strain SO52-3 could be due to the occurrence of phage lysins present in the lysates. Their actions are similar to the activity of lysozyme.

In conclusion, in this study we have determined 22 genotypically different strains that could be further used in industrial applications. They show differences 
in acidification speed, EPS production and most importantly the lactococcal isolates are resistant to phages representing the major phage families found in dairies.

Address for correspondence: Aleksandra Martinović, M.Sc.

Institute of Meat Hygiene and Technology

Kaćanskog 13, 11000 Belgrade,

Serbia\& Montenegro

E-mail: aleksmartinovic@cg.yu

\section{REFERENCES}

1. Andersson DG, McKay LL, 1983, Simple and rapid method for isolating large plasmid DNA from Lactococcal Streptococci, Appl Environ Microbiol, 46, 549-52.

2. Davies FL, Underwood HM, Gasson MJ, 1981, The value of plasmid profiles for strains identification in lactic streptococci and the relationship between Streptococcus lactis 712, ML3 and C2, $J$ Appl Bacteriol, 51, 325- 37.

3. De Man JC, Rogosa M, Sharpe ME, 1960, A medium for the cultivation of lactobacilli, J Appl. Bacteriol, 23, 130-5.

4. Dozet Natalija, Adžić N, Stanišić M, Živić N, 1996, Autohtoni mlječni proizvodi. Poljoprivredni institut Podgorica, SILMIR-Beograd,1996.

5. Ferrero M, Casena C, Morelli L, Scolari G, Vescovo M, 1996, Molecular characterization of Lactobacillus casei strains. FEMS Microbiol Letters, 140, 215-9.

6. Higgins AR, Sandine WE, 1997, Incidence and properties of temperate bacteriophages induced from lactic streptococci, Appl Environ Microbiol, 33, 184-91.

7. Holloway BW, Morgan AF, 1986, Genome organization in Pseudomonas, Ann Rev Microbiol, 40, 79105.

8. Hung P, Bandziulis C, 1990, Megabase DNA Analysis: Chromosomal DNA Preparation, Restriction and Pulsed-Field Electrophoresis, Promega Notes, 24, 1-3.

9. Jarvis AW, Wolff JM, 1979, Grouping of lactic streptococci by gel electrophoresis of soluble cell extracts, Appl Environ Microbiol, 37, 391-8.

10. Le Bourgeois P, Mata, M, Ritzenthaler P, 1989, Genome comparison of Lactococcus strains by pulsed-field gel electrophoresis, FEMS Microbiol Lett, 59, 65-70.

11. Pot B, Hertel C, Ludwig W, Descheemaeker P, Kersters K, Schleifer K, 1993, Identification and classification of Lactobacillus acidophilus, $L$. gasseri and $L$. johnsonii strains by SDS-PAGE and rRNA-targeted oligonucleotide probe hybridization, $J$ Gen Microbiol, 139, 513-7.

12. Rilez M, Anilionis A, 1978, Evolution of the bacterial genome, Ann Rev Microbiol, 32, 519-60.

13. Salminen S, von Wright A, 1998, Lactic Acid Bacteria. Marcel Dekker, Inc., 1998.

14. Tanasken El, Tulloch D, Hiller AJ, Davidson BE, 1990, Pulsed-Field gel Electrophoresis of Smal digests of Lactococcal genomic DNA, a novel method of strain identification, Appl Environ Microbiol, 10, 3105-11.

15. Terzagi BE, Sandine WE, 1975, Improved medium for lactic streptococci and their bacteriophages. Appl Microbiol, 29, 807-13.

16. Torriani S, Felis GE, Dellaglio F, 2001, Differentiation of Lactobacillus plantarum, L. pentosus, and $L$. paraplantarum by recA Gene Sequence Analysis and Multiplex PCR Assay with recA GeneDerived Primers, Appl Environ Microbiol, 67, 3450-4.

17. Tynkkynen S, Satokari R, Saarela M, Mattila-Sandholm T, Saxelin M, 1999, Comparisom of Ribotyping, Randomly Amplified polymorphic DNA analysis and Pulsed-Gel Field Electrophoresis in typing of Lactobacillus rhamnosus and L. casei strains, Appl Environ Microbiol, 9, 3908-14. 
18. Urbach E, Daniels B, Salama MS, Sandine WE, Giovannoni SJ, 1997, The Idh phylogeny for environmental isolates of Lactoccus lactis is consistent with rRNA genotypes but not with phenotypes, Appl Environ Microbiol, 63, 694-702.

19. Vedemutuhu ER, Neville JM, 1986, Involvement of a plasmid in production of ropiness (mucoidness) in milk cultures by Streptococcus cremoris MS, Appl Environ Microbiol, 51, 667.

20. Vogensen FK, 1987, Improved direct differentiation between Leuconostoc cremoris, Streptococcus lactis subsp. Diacetylactis and Streptococcus cremoris / Streptococcus lactis on agar, Milchwissenschaft, 42.

\title{
IZOLACIJA I KARAKTERIZACIJA BAKTERIJSKE FLORE IZ AUTOHTONIH FERMENTISANIH PROIZVODA SRBIJE I CRNE GORE
}

\author{
MARTINOVIĆ ALEKSANDRA, RADULOVIĆ ZORICA, WIND ANETTE, JANZEN ANETTE i \\ OBRADOVIĆ D
}

\section{SADRŽAJ}

U ovom radu su proučavani sojevi bakterija mlečne kiseline izolovani iz autohtonih fermentisanih mlečnih proizvoda. Kod ovih proizvoda, kojima se ne dodaju starter kulture, fermentacija se odigrava kao rezultat aktivnosti prirodne mikroflore koja je prisutna u okolnoj sredini. Kod ukupno 200 sojeva proučavana je njihova sposobnost acidifikacije i sposobnost stvaranja egzopolisaharida (EPS). Od ukupno 200 izolovanih sojeva selektovano je njih 27 koji su podvrgnuti daljem proučavanju. Nakon ove selekcije, sojevi su identifikovani 16S rRNA sekvenciranjem u cilju njihove identifikacije na nivou vrste. Od 27 selektovanih sojeva, 14 je pripadalo vrsti Lactococcus lactis subsp. Lactis, 3 soja je pripadalo vrsti Leuconostoc spp., dok je 10 sojeva pripadalo vrsti Lactobacillus sp. Da bi se utvrdile razlike između različitih sojeva urađena je analiza uz korišćenje elektroforeze u pulsirajućem električnom polju (PFGE), a matrice su dobijene uz korišćenje Smal i Ascl restrikcionih enzima. Sojevi koji nisu u srodstvu dali su različite matrice digestionih produkata. Izvršena je i izolacija plazmida iz ovih sojeva kako bi se potvrdili rezultati dobijeni PFGE tehnikom. Takođe je izvršena i fagotipizacija sojeva za sve sojeve za koje je dokazano da pripadaju vrsti Lactococcus sp. Svi laktokokni sojevi su bili rezistentni na 41 fag (kolekcija faga kompanije Chr. Hansen) koji predstavljaju grupu bakteriofaga koji su najčešći za vrstu Lactococcus. Dobijeni rezultati ukazuju na to da proučavani sojevi predstavljaju mogući izvor kultura koji do sada nisu bili izloženi bilo kakvoj industrijskoj selekciji. 